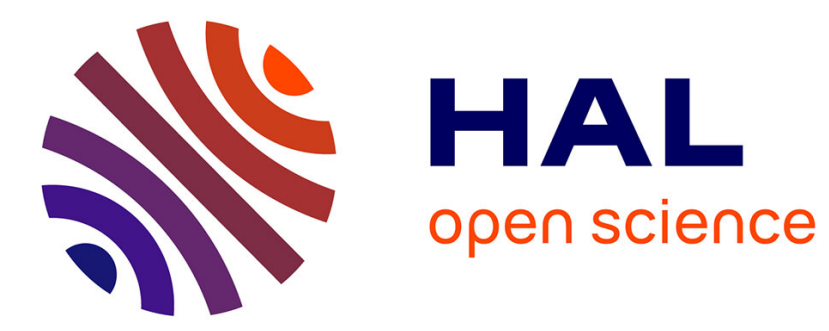

\title{
One-Pot Synthesis of 2,5-Disubstituted Furans through In Situ Formation of Allenes and Enolization Cascade
}

Yann Bernhard, Joachim Gilbert, Till Bousquet, Audrey Favrelle-Huret, Philippe Zinck, Sylvain Pellegrini, Lydie Pelinski

\section{- To cite this version:}

Yann Bernhard, Joachim Gilbert, Till Bousquet, Audrey Favrelle-Huret, Philippe Zinck, et al.. OnePot Synthesis of 2,5-Disubstituted Furans through In Situ Formation of Allenes and Enolization Cascade. European Journal of Organic Chemistry, 2019, European Journal of Organic Chemistry, 2019 (48), pp.7870-7873. 10.1002/ejoc.201901669 . hal-03263313

\section{HAL Id: hal-03263313 \\ https://hal.science/hal-03263313}

Submitted on 17 Jun 2021

HAL is a multi-disciplinary open access archive for the deposit and dissemination of scientific research documents, whether they are published or not. The documents may come from teaching and research institutions in France or abroad, or from public or private research centers.
L'archive ouverte pluridisciplinaire HAL, est destinée au dépôt et à la diffusion de documents scientifiques de niveau recherche, publiés ou non, émanant des établissements d'enseignement et de recherche français ou étrangers, des laboratoires publics ou privés. 


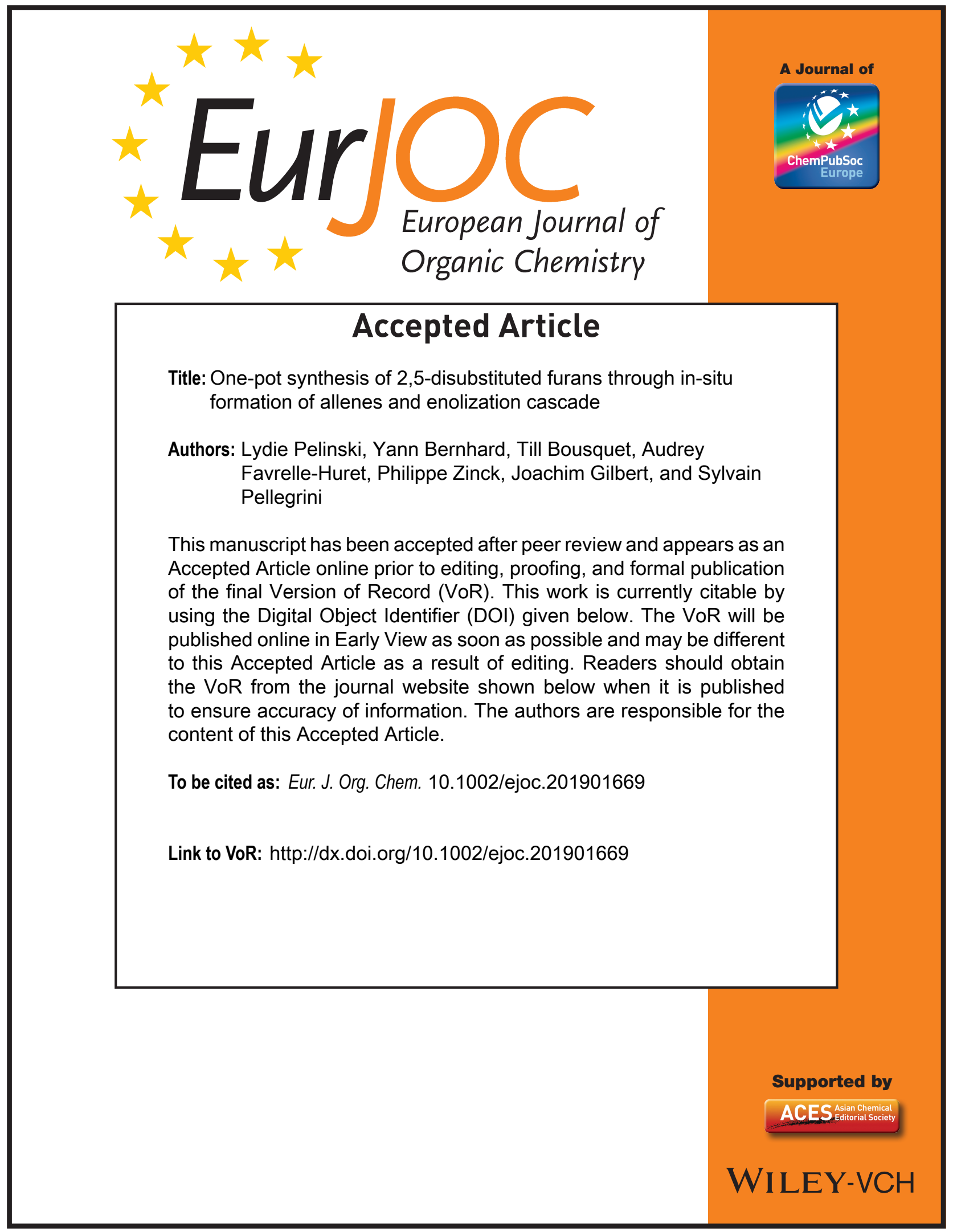




\title{
One-pot synthesis of 2,5-disubstituted furans through in-situ formation of allenes and enolization cascade
}

\author{
Yann Bernhard, Joachim Gilbert, Till Bousquet, Audrey Favrelle-Huret, Philippe Zinck, Sylvain \\ Pellegrini, and Lydie Pelinski*[a]
}

Dedication ((optional))

\begin{abstract}
A one-pot synthesis of 2,5-disubstituted furans from $\gamma$ ketoacids is reported. In situ formation of allenoates by action of chloroformate on carboxylic acid following by enolization of ketone affords to furan derivatives by cyclization. The reaction was extended on a wide scope of ketoacids and phosphonium salts. This methodology was applied on levulinic acid and derivatives, one of the biosourced platform chemicals.
\end{abstract}

Substituted furans represent an important class of heterocycles, often found in bioactive natural products and pharmacologically active compounds. ${ }^{[1]}$ As such the attractiveness of furancontaining structures lead to a continuous development of new efficient methods for the synthesis of this heterocycle. ${ }^{[2]}$ Among the many approaches explored towards their synthesis, homogeneous metal-catalyzed reactions are attractive due to their efficiency and functional group compatibility. ${ }^{[3]}$ Particularly, a strategy involving cycloisomerization of alkyne using transitionmetal catalysts such as rhodium, copper, gold, and palladium complexes is the most studied. ${ }^{[4]}$ In contrast to metal-mediated processes, organocatalytic approaches to the construction of substituted furan are also described. ${ }^{[5]}$ Recently, a convenient scandium(III) triflate-catalyzed synthesis of 2,5-disubstituted furans was developed by employing oxiranes with $\gamma$ hydroxyenones. ${ }^{[6]}$

Allenes are highly valuable synthetic precursors in preparative organic chemistry due to their high reactivity and rich chemistry associated with the two orthogonal carbon-carbon double bounds. ${ }^{[7]}$ Among the transformations investigated, the transitionmetal-catalyzed intramolecular hydrofunctionalization of allenes with heteroatom nucleophiles displays an elegant approach for the synthesis of heterocycles. ${ }^{[8]}$ Particularly, allenyl ketones or alcohols (Scheme 1, pathway a ${ }^{[9]}$ and allenyl amides (Scheme 1, pathway $b)^{[10]}$ are common starting materials for transition-metal catalyzed furan synthesis. ${ }^{[11]}$ More recently, multisubstituted furans were obtained by reaction of an allenoate with $\alpha$ halocarbonyl ketones or dicarbonyl compounds(Scheme 1, pathway c). ${ }^{[12]}$

[a] Dr. Y. Bernhard, J. Gilbert, Dr. T. Bousquet, Dr A. Favrelle-Huret, Prof. P. Zinck, Dr. S. Pellegrini, Prof. Dr. L. Pelinski Univ. Lille, ENSCL, Centrale Lille, Univ. Artois, UMR 8181-UCCSUnité de Catalyse et Chimie du Solide, F-59000 Lille, France E-mail: lydie.pelinski@univ-lille.fr

http://uccs.univ-lille1.fr/index.php/fr/catalyse-chimiemoleculaire/caseco

Supporting information for this article is given via a link at the end of the document.((Please delete this text if not appropriate))

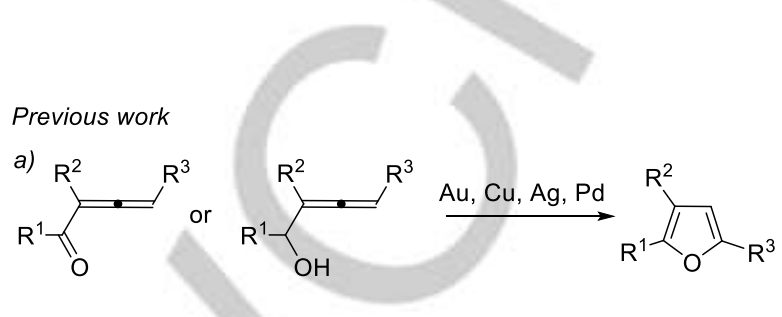

b)
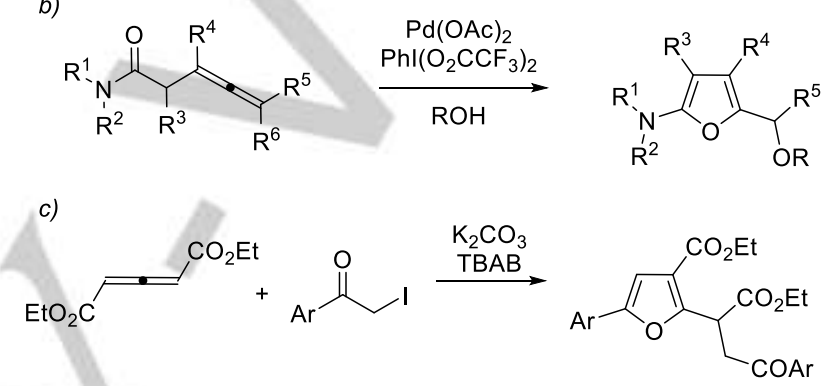

This work

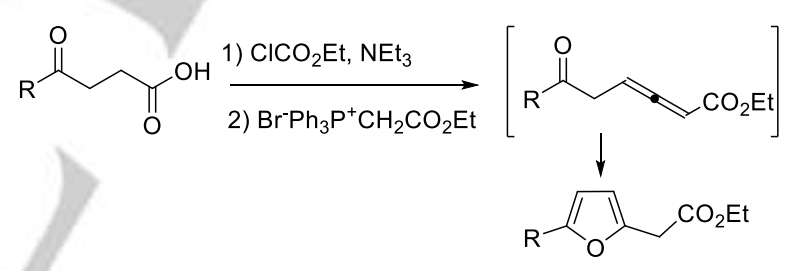

Scheme 1. Previous studies and our contribution on furan synthesis

Despite these processes, there is still a requirement to develop new and efficient strategies particularly based on easily accessible starting materials. To this end, we developed a onepot synthesis of 2,5-disubtituted furans involving an unprecedented formation of allenes as key intermediates (Scheme 1). It is worth noting that the most useful synthesis of allenes consists of a Wittig reaction by reacting a phosphorane or phosphonium salt with activated carboxylic acids such as acid chlorides. ${ }^{[13]}$ In our study, we propose the possibility to use chloroformates as an alternative to thionyl chloride and oxalyl chloride as activating reagent of carboxylic acid.

We initiated our study with 3-benzoyl propionic acid 1a as a model substrate. In a typical procedure, the ketoacid 1a (1 equiv) was first activated by the chloroformate 2 (1 equiv) in the presence of triethylamine (2 equiv) in dichloromethane at $0{ }^{\circ} \mathrm{C}$. After $10 \mathrm{~min}$, the phosphonium salt 3 ( 0.5 equiv) was added and the mixture was refluxed for $10 \mathrm{~h}$ (Table 1). After screening various chloroformates (entries 1-4), we discovered that the desired furan product $4 a$ was formed in $82 \%$ yield in the presence of ethyl chloroformate (entry 2). When the reaction was performed with an equimolar quantity of ketoacid $1 \mathrm{a}$ and phosphonium salt, the yield 
dropped from 82 to $62 \%$ (Entry 5). Likewise, the reaction did not proceed to completion at room temperature (entry 6). With the exception of replacing the dichloromethane by dimethylformamide (entry 12), the solvents were found to decrease the yields of the transformation of ketoacid (entries 711).

The mechanism suggested for this transformation is outlined in Scheme 2. In a first step, the ketoacid reacts with ethyl chloroformate in the presence of triethylamine to form the mixed anhydride carbonate. The latter by action of the phosphonium salt leads to the allene which readily undergoes intramolecular cyclization to furnish the furan derivative. It is worth noting that the assumption of allene formation was confirmed when an additional reaction was set from 3-phenylpropionic acid. In fact, this substrate, which is unable to perform the last cyclization step, allows to isolate the allene in a $60 \%$ yield.

$$
\text { (I) }
$$

With the optimized conditions in hand, we began to investigate the scope of the method. At first, different kinds of substituted benzoylpropionic acids, easily prepared by a Friedel-Crafts reaction between substituted benzene derivatives and succinic anhydride, were evaluated. As shown in Table 2, a broad range of benzoylpropionic acids bearing electron-donating and withdrawing substituents reacted smoothly with the phosphonium salt $\mathbf{3}$ in moderate to good yields. The best result of $93 \%$ yield was obtained from the meta-nitro substituted substrate. Additionally, electron donating groups such as methoxy, alkyl substituents are compatible with the reaction conditions. However, the lower $56 \%$ yield observed for the synthesis of $\mathbf{4 d}$ was likely due to the steric hindrance of the methoxy moiety in the ortho position. The presence of halogens on the benzene ring did not affect the yield $(73 \%$ for $\mathbf{4 g}$ and $70 \%$ for $\mathbf{4 h}$ ). The ferrocenyl furan $\mathbf{4 j}$ was obtained in only $35 \%$ yield due to heat decomposition.

The scope of the reaction was then extended to various phosphonium salts containing other functions such as ketones or nitrile (Table 3). Apart from furan 6a (56\% yield), the condensation of phosphonium salt $\mathbf{5}$ led to furan derivatives in good $65-86 \%$ yields.

Table 2. Scope of the ketoacid substrates

\begin{tabular}{|c|c|c|c|}
\hline 1a & $\begin{array}{l}\text { 1) } \mathrm{ClCO}_{2} \mathrm{R} 2(1 \\
\text { solvent, } 0^{\circ} \mathrm{C} \\
\text { 2) } \mathrm{Br}^{-} \mathrm{Ph}_{3} \mathrm{P}^{+} \mathrm{CH} \\
45^{\circ} \mathrm{C}, 10 \mathrm{~h}\end{array}$ & $\begin{array}{l}\text { 1) } \mathrm{ClCO}_{2} \mathrm{R} 2 \text { ( } 1 \text { equiv), } \mathrm{NEt}_{3} \text { (2 equiv) } \\
\text { solvent, } 0^{\circ} \mathrm{C}, 10 \mathrm{~min}\end{array}$ & \\
\hline Entry & 2 & Solvent & \\
\hline 1 & $\mathrm{ClCO}_{2} \mathrm{Me}$ & $\mathrm{CH}_{2} \mathrm{Cl}_{2}$ & 68 \\
\hline 2 & $\mathrm{ClCO}_{2} \mathrm{Et}$ & $\mathrm{CH}_{2} \mathrm{Cl}_{2}$ & 82 \\
\hline 3 & $\mathrm{ClCO}_{2} i-\mathrm{Bu}$ & $\mathrm{CH}_{2} \mathrm{Cl}_{2}$ & 68 \\
\hline 4 & $\mathrm{ClCO}_{2} p-\mathrm{NO}$ & $\mathrm{CH}_{2} \mathrm{Cl}_{2}$ & 0 \\
\hline $5^{[c]}$ & $\mathrm{ClCO}_{2} \mathrm{Et}$ & $\mathrm{CH}_{2} \mathrm{Cl}_{2}$ & 62 \\
\hline $6^{[d]}$ & $\mathrm{ClCO}_{2} \mathrm{Et}$ & $\mathrm{CH}_{2} \mathrm{Cl}_{2}$ & 38 \\
\hline 7 & $\mathrm{ClCO}_{2} \mathrm{Et}$ & $\mathrm{CHCl}_{3}$ & 62 \\
\hline 8 & $\mathrm{ClCO}_{2} \mathrm{Et}$ & $\mathrm{CH}_{3} \mathrm{CN}$ & 76 \\
\hline 9 & $\mathrm{ClCO}_{2} \mathrm{Et}$ & Dioxane & 38 \\
\hline 10 & $\mathrm{ClCO}_{2} \mathrm{Et}$ & 1,2-DCE & 70 \\
\hline 11 & $\mathrm{ClCO}_{2} \mathrm{Et}$ & Toluene & 23 \\
\hline 12 & $\mathrm{ClCO}_{2} \mathrm{Et}$ & DMF & 79 \\
\hline
\end{tabular}

Scheme 2. Proposed mechanism

Table 1. Optimisation of the reaction conditions ${ }^{[a]}$

[a] Reaction conditions: 1a (1.28 mmol), 2 (1.28 mmol), NEt ${ }_{3}(300 \mu \mathrm{L}), .3(0.64$ $\mathrm{mmol})$, solvent $(10 \mathrm{~mL})$. [b] Isolated yield. [c] In presence of $1.28 \mathrm{mmol}$ of $\mathbf{3}$. [d] RT.

$$
\text { 1b-k }
$$

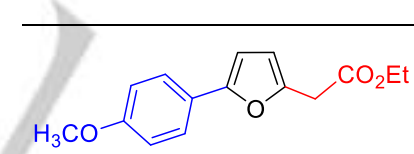

4b, $74 \%$<smiles>CCOC(=O)Cc1ccc(-c2cc(OC)ccc2OC)o1</smiles><smiles>CCOC(=O)Cc1ccc(-c2ccc(C)c(C)c2)o1</smiles>

4f, $69 \%$<smiles>CCOC(=O)Cc1ccc(-c2ccc(Cl)cc2)o1</smiles>

4h, $70 \%$

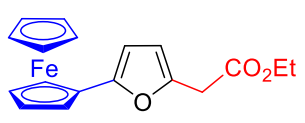

4j, $35 \%$<smiles>CCOC(=O)Cc1ccc(-c2ccc(OC)c(OC)c2)o1</smiles>

4c, $75 \%$<smiles>CCOC(=O)Cc1ccc(-c2ccc(C(C)(C)C)cc2)o1</smiles>

4e, $66 \%$<smiles>CCOC(=O)Cc1ccc(-c2ccc(Br)cc2)o1</smiles>

4g, $73 \%$<smiles>CCOC(=O)Cc1ccc(-c2cccc([N+](=O)[O-])c2)o1</smiles>

$4 i, 83 \%$<smiles>CCOC(=O)Cc1ccc(-c2ccc3ccccc3c2)o1</smiles>

4k, $64 \%$

\section{r}

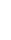


[a] Reaction conditions: $\mathbf{1}(1.28 \mathrm{mmol}), 2(140 \mu \mathrm{L}), \mathrm{NEt}_{3}(300 \mu \mathrm{L}), 3(0.64$ $\mathrm{mmol})$, solvent $(10 \mathrm{~mL})$. Yields of the isolated product are given.

Table 3. Scope of the phosphonium salt

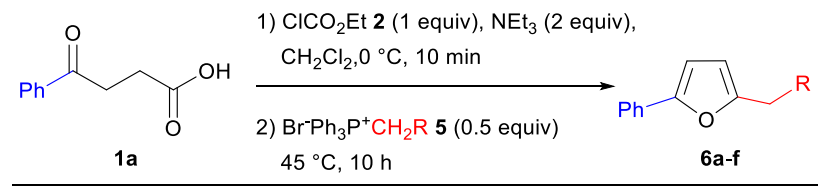<smiles>O=C(Cc1ccc(-c2ccccc2)o1)c1ccccc1</smiles>

6a, $56 \%$<smiles>COc1ccc(C(=O)Cc2ccc(-c3ccccc3)o2)cc1</smiles>

6c, $70 \%$<smiles>Cc1ccc(C(=O)Cc2ccc(-c3ccccc3)o2)cc1</smiles>

6b, $86 \%$<smiles>O=C(Cc1ccc(-c2ccccc2)o1)c1ccc(Br)cc1</smiles>

6d, $65 \%$<smiles>N#CCc1ccc(-c2ccccc2)o1</smiles>

[a] Reaction conditions: 1a $(1.28 \mathrm{mmol}), \mathbf{2}(140 \mu \mathrm{L}), \mathrm{NEt}_{3}(300 \mu \mathrm{L}), \mathbf{5}(0.64$ $\mathrm{mmol})$, solvent $(10 \mathrm{~mL})$. Yields of the isolated product are given.

Finally, this new synthetic method was performed from the levulinic acid 7, a promising biosourced platform chemical (Scheme 3). ${ }^{[14]}$ The furan $4 \mathbf{I}$ was then isolated in a good yield of $65 \%$. Additionally, the ketoacid 10, obtained by reaction of ethyl levulinate 9 on benzaldehyde following by hydrolysis of ester, led the the furan $4 \mathrm{~m}$ with a disappointing yield of $34 \%$. A degradation of the mixture was observed during the synthesis. The reaction of levulinic acid-based phosphonium salt 11 on benzoylpropionic acid $\mathbf{1}$ led to the furanyl ketoester $\mathbf{6 g}$ in a modest yield of $46 \%$.

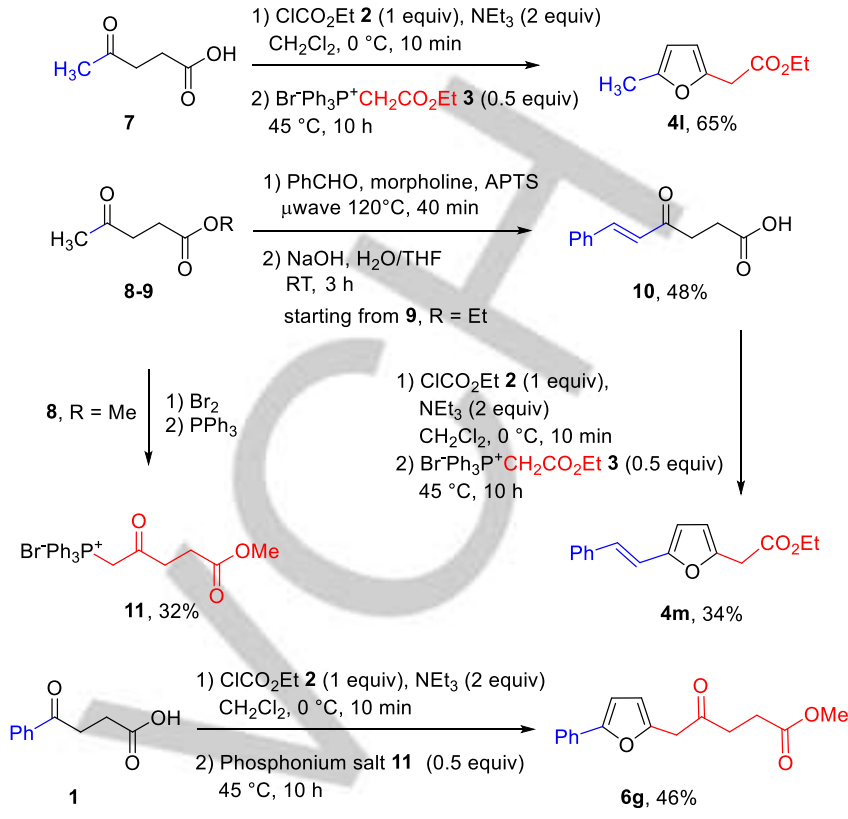

Scheme 3. Furan synthesis starting from levulinic acid derivatives

In conclusion, we have developed an efficient method for the synthesis of 2,5-disusbtituted furans from $\gamma$-ketoacids. The reaction is operationally simple and presents a wide substrate scope. This methodology was further extended to levulinic acid and derivatives in order to valorize a promising biobased platform chemical.

\section{Experimental Section}

Typical procedure for the one-pot synthesis of 2,5-disubsituted furans: to ketoacid $(1.28 \mathrm{mmol})$ in $\mathrm{CH}_{2} \mathrm{Cl}_{2}(10 \mathrm{~mL})$ was added triethylamine $(2.15 \mathrm{mmol})$ then ethylchloroformate $(1.47 \mathrm{mmol})$ at $0^{\circ} \mathrm{C}$. After stirring for $10 \mathrm{~min}$, the phosphonium salt $(0.64 \mathrm{mmol})$ was added and the mixture was heated under reflux for $10 \mathrm{~h}$. The mixture was neutralized by aqueous $\mathrm{HCl}$ solution $1 \mathrm{M}$ and extracted with $\mathrm{CH}_{2} \mathrm{Cl}_{2}(3 \times 15 \mathrm{~mL})$. The combined organic layers were dried over $\mathrm{MgSO}_{4}$ and concentrated in vacuo. The product was purified by column chromatography over silica gel (eluent: petroleum ether/diethylether $9 / 1$ then petroleum ether/diethylether $7 / 3$ ) to give the furan derivatives.

Full experimental details and characterization data are given in the Supporting Information.

\section{Acknowledgements}

This work was financially supported by the FWV ALPO Interreg Grant. Chevreul institute (FR 2638), Ministère de l'Enseignement Supérieur et de la Recherche, Région Nord - Pas-de-Calais and FEDER are acknowledged for supporting and funding this work. We also would like to thank Céline Delabre for her technical support.

Keywords: Furan derivatives - phosphonium salt • allene intermediate $\cdot$ levulinic acid

[1] a) B. A. Keay, J. M. Hopkins, P. W. Dibble, In Comprehensive Heterocyclic Chemistry III, Vol. 3 (Eds.: A. R. Katritzky, C. A. Ramsden, 
E. F. V. Scriven, R. J. K. Taylor), Elsevier, Amsterdam, 2008, pp 571; b) K.-S. Yeung, X.-S. Peng, J. Wu, R. Fan, X.-L. Hou, Prog. Heterocycl. Chem. 2013, 25, 183; c) Y. Wang, Y.-C. Luo, X.-Q. Hu, P.-F. Xu, Org. Lett. 2011, 13, 5346; d) C.-C. Wu, W.-Y. Hung, T.-L. Liu, L.-Z. Zhang, T.Y. Luh, J. Appl. Phys. 2003, 93, 5465; e) M. D. Mullican, R. J. Sorenson, D. T. Connor, D. O. Thueson, J. A. Kennedy, M. C. Conroy, J. Med Chem. 1991, 34, 2186; f) S. N. Abramson, J. A. Trischman, D. M. Tapiolas, E. E. Harold, W. Fenical, P. Taylor, J. Med. Chem. 1991, 34, 1798; g) B. Tang, C. D. Bray, G. Pattenden, J. Rogers, Tetrahedron 2010 66,$2492 ;$ h) S. M. Rahmathullah, J. E. Hall, B. C. Bender, D. R. McCurdy, R. R. Tidwell, D. W. Boykin, J. Med. Chem. 1999, 42, 3994; i) D. S. Mortensen, A. L. Rodriguez, K. E. Carlson, J. Sun, B. S. Katzenellenbogen, J. Katzenellenbogen, J. Med. Chem. 2001, 44, 3838.

[2] a) J. Shen, J. Zhao, B. Hu, Y. Chen, L. Wu, Q. You, L. Zhao, Green Chem. 2018, 20, 600; b) S. F. Kirsch, Org. Biomol. Chem. 2006, 4, 2076; c) T. J. Donohoe, J. F. Bower, Proc. Natl. Acad. Sci. U. S. A. 2010, 107, 3373 d) Keay, B. A. Chem. Soc. Rev. 1999, 28, 209; e) Y. Xiao, J. Zhang, Chem. Commun. 2009, 3594.

[3] a) A. S. Karpov, E. Merkul, T. Oeser, T. J. J. Müller, Chem. Commun. 2005, 2581; b) A. V. Gulevich, A. S. Dudnik, N. Chernyak, V. Gevorgyan, Chem. Rev. 2013, 113, 3084; c) S. P. Morcillo, D. Leboeuf, C. Bour, V. Gandon, Chem. Eur. J. 2016, 22, 16974.

[4] a) M. Zhang, H.-F. Jiang, H. Neumann, M. Beller, P. H. Dixneuf, Angew. Chem., Int. Ed. 2009, 48, 1681; b) A. V. Kelin, V. Gevorgyan, J. Org. Chem. 2002, 67, 95; c) J. T. Kim, A. V. Kelin, V. Gevorgyan, Angew. Chem., Int. Ed. 2003, 42, 98; d) A. W. Sromek, A. V. Kelin, V. Gevorgyan, Angew. Chem., Int. Ed. 2004, 43, 2280; e) A. Gille, J. Rehbein, M. Hiersemann, Org. Lett. 2011, 13, 2122; f) M. H. Suhre, M. Reif, S. F. Kirsch, Org. Lett. 2005, 7, 3925; g) H. Cao, H. Jiang, R. Mai, S. Zhu, C. Qia, Adv. Synth. Catal. 2010, 352, 143. h) C. Arroniz, G. Chaubet, E. A Anderson, ACS Catal. 2018, 8, 8290.

[5] a) C.-K. Jung, J.-C. Wang, M. J. Krische, J. Am. Chem. Soc. 2004, 126 4118; b) L. Albrecht, L. K. Ransborg, B. Gschwend, K. A. Jørgensen, J. Am. Chem. Soc. 2010, 132, 17886; c) H. Kuroda, E. Hanaki, H. Izawa M. Kano, H. Itahashi, Tetrahedron 2004, 60, 1913; d) J. S. Clark, A Boyer, A. Aimon, P. E. García, D. M. Lindsay, A. D. F. Symington, Y Danoy, Angew. Chem. Int. Ed. 2012, 51, 12128.

[6] K. Mondal, S. C. Pan, J. Org. Chem. 2017, 82, 4415.

[7] a) S. Ma, Chem. Rev. 2005, 105, 2829; b) S. Yu, S. Ma, Angew. Chem. Int. Ed. 2012, 51, 3074; c) B. Alcaide, P. Almendros, C. Aragoncillo, Chem. Soc. Rev. 2014, 43, 3106; d) R. Zimmer, H.-U. Reissig, Chem. Soc. Rev. 2014, 43, 2888; e) K. M. Brummond, J. E. DeForrest, Synthesis 2007, 6, 795.
[8] a) O. El-Sepelgy, A. Brzozowska, J. Sklyaruk, Y. K. Jang, V. Zubar, M. Rueping, Org. Lett. 2018, 20, 696; b) S. Ma, Acc. Chem. Res. 2003, 36 701 ; c) S. Pashikanti, J. A. Calderone, M. K. Nguyen, C. D. Sibley, W. L. Santos, Org. Lett. 2016, 18, 2443; d) Z. Zhang, C. Liu, R. E. Kinder, X. Han, H. Qian, R. A. Widenhoefer, J. Am. Chem. Soc. 2006, 128, 9066; e) Z. Zhang, R. A. Widenhoefer, Angew. Chem. Int. Ed. 2007, 46, 283.

[9] a) N. Krause, C. Winter, Chem. Rev. 2011, 111, 1994; b) A. W. Sromek, M. Rubina, V. Gevorgyan, J. Am. Chem. Soc. 2005, 127, 10500; c) S Ma, J. Zhang, L. Lu, Chem.-Eur. J. 2003, 9, 2447; d) J. A. Marshall, X.J. Wang, J. Org. Chem. 1991, 56, 960; e) J. A. Marshall, E. D. Robinson, J. Org. Chem. 1990, 55, 3450; f) A. S. K. Hashmi, L. Schwarz, J.-H. Choi, T. M. Frost, Angew. Chem. Int. Ed. 2000, 39, 2285; g) Y. Li, J. P. Brand, J. Waser, Angew. Chem. Int. Ed. 2013, 52, 6743. A. S. K. Hashmi, Angew. Chem. Int. Ed. 1995, 34, 1581; h) Y. Xia, A. S. Dudnik, V. Gevorgyan, Y. Li, J. Am. Chem. Soc. 2008, 130, 6940; i) Z. Zhang, C. Liu, R. E. Kinder, X. Han, H. Qian, R. A. Widenhoefer, J. Am. Chem. Soc. 2006, 128, 9066; j) Z. Zhang, R. A. Widenhoefer, Angew. Chem. Int. Ed. 2007, 46, 283

[10] a) J. Zhang, M. Wu, W. Lu, S. Wang, Y. Zhang, C. Cheng, G. Zhu, J. Org. Chem. 2017, 82, 11134; b) Y. Wan, J. Zhang, Y. Chen, L. Kong, F. Luo G. Zhu, Org. Biomol. Chem. 2017, 15, 7204.c) A. Kondoh, S. Ishikawa, T. Aoki, M. Terada, Chem. Commun. 2016, 52, 12513.

[11] a) A. S. K. Hashmi, in Modern Allene Chemistry, Vol. 2 (Eds.: Norbert Krause and A. Stephen K. Hashmi), Wiley-VCH, Weinheim, 2004, pp 889; b) R. C. D. Brown, Angew. Chem. Int. Ed. 2005, 44, 850.

[12] D. Bakshi, A. Singh, Org. Biomol. Chem. 2017, 15, 3175

[13] a) R. W. Lang, H.-J. Hansen, Helv. Chim. Acta 1980, 63, 438; b) H.-J. Bestmann, H. Hartung, Chem. Ber. 1966, 99, 1198; b) E. Kohl-Mines, H.J. Hansen, Helv. Chim. Acta 1985, 68, 2244; c) R. W. Lang, H.-J. Hansen, Org. Synth. 1984, 62, 202; d) K. Kumar, S. Kaur, M. P. S. Ishar, Synlett 1999, 1237.

[14] a) U. Omoruyi, S. Page, J. Hallett, P. W. Miller, ChemSusChem 2016, 9 , 2037; b) B. V. Timokhin, V. A. Baransky, G. D. Eliseeva, Russ. Chem Rev. 1999, 68, 73; c) Z. Xue, Q. Liu, J. Wang, T. Mu, Green Chem. 2018, 20, 4391; d) L. Yan, Q. Yao, Y. Fu, Green Chem., 2017, 19, 5527-5547; e) L. Hu, J. Xu, S. Zhou, A. He, X. Tang, L. Lin, J. Xu, Y. Zhao, ACS Catal. 2018, 8, 2959. 
Entry for the Table of Contents (Please choose one layout)

Layout 1:

\section{COMMUNICATION}

Text for Table of Contents

Layout 2:

\section{COMMUNICATION}

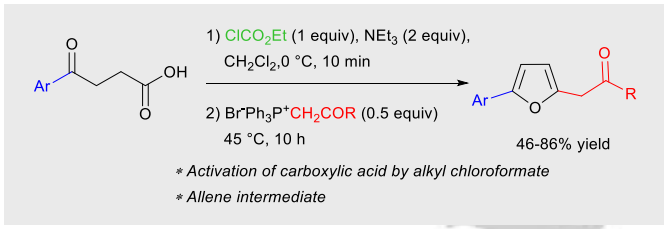

Y. Bernhard, J. Gilbert, T. Bousquet, A. Favrelle-Huret, P. Zinck, S. Pellegrini, L. Pelinski *

Page No. - Page No.

Title

Furan synthesis: A one-pot synthesis of 2,5-disubstituted furans from $\gamma$-ketoacids is reported. In situ formation of allenoates by action of chloroformate on carboxylic acid following by enolization of ketone affords to furan derivatives by cyclization.

Page No. - Page No.

Title

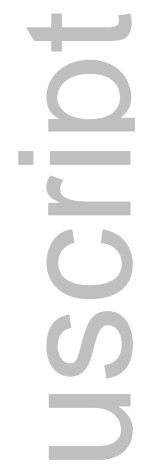

๘ে

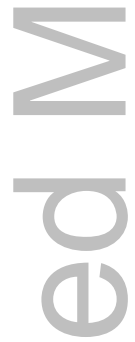

